Georgia State University

ScholarWorks @ Georgia State University

$5-1-2021$

\title{
Performances in COVID 19 Management Across Countries: Do Subnational Finances Matter?
}

Simanti Bandyopadhyay

Shiv Nadar University, simantib@gmail.com

Sujana Kabiraj

University of Wisconsin - Stevens Point

Subrata Majumder

Sundarban Mahavidyalaya

Follow this and additional works at: https://scholarworks.gsu.edu/icepp

\section{Recommended Citation}

Bandyopadhyay, Simanti; Kabiraj, Sujana; and Majumder, Subrata, "Performances in COVID 19 Management Across Countries: Do Subnational Finances Matter?" (2021). ICEPP Working Papers. 109.

https://scholarworks.gsu.edu/icepp/109

This Article is brought to you for free and open access by the International Center for Public Policy at ScholarWorks @ Georgia State University. It has been accepted for inclusion in ICEPP Working Papers by an authorized administrator of ScholarWorks @ Georgia State University. For more information, please contact scholarworks@gsu.edu. 
International Center for Public Policy

Working Paper 21-10

May 2021

Performances in COVID 19 Management Across Countries: Do Subnational Finances Matter?

Simanti Bandyopadhyay

Sujana Kabiraj

Subrata Majumder 



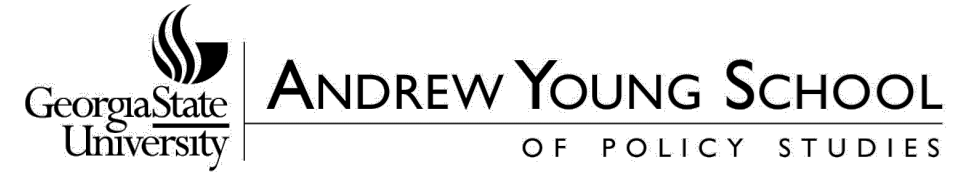

\author{
International Center for Public Policy \\ Working Paper 21-10
}

\section{Performances in COVID-19 Management Across Countries: Do Subnational Finances Matter?}

\section{Simanti Bandyopadhyay \\ Sujana Kabiraj \\ Subrata Majumder}

\section{May \\ 2021}

International Center for Public Policy

Andrew Young School of Policy Studies

Georgia State University

Atlanta, Georgia 30303

United States of America

Phone: (404) 413-0235

Fax: (404) 651-4449

Email: paulbenson@gsu.edu

Website: http://icepp.gsu.edu/

Copyright 2021, the Andrew Young School of Policy Studies, Georgia State University. No part of the material protected by this copyright notice may be reproduced or utilized in any form or by any means without prior written permission from the copyright owner. 


\section{$\underset{\substack{\text { Georgastate } \\ \text { University }}}{\int \text { ANDREW YOUNG SCHOOL }}$}

\section{International Center for Public Policy Andrew Young School of Policy Studies}

The Andrew Young School of Policy Studies was established at Georgia State University with the objective of promoting excellence in the design, implementation, and evaluation of public policy. In addition to two academic departments (economics and public administration), the Andrew Young School houses seven leading research centers and policy programs, including the International Center for Public Policy.

The mission of the International Center for Public Policy (ICePP) at the Andrew Young School of Policy Studies is to provide academic and professional training, applied research, and technical assistance in support of sound public policy and sustainable economic growth in developing and transitional economies.

ICePP is recognized worldwide for its efforts in support of economic and public policy reforms through technical assistance and training around the world. This reputation has been built serving a diverse client base, including the World Bank, the U.S. Agency for International Development (USAID), the United Nations Development Programme (UNDP), finance ministries, government organizations, legislative bodies, and private sector institutions.

The success of ICePP reflects the breadth and depth of its in-house technical expertise. The Andrew Young School's faculty are leading experts in economics and public policy and have authored books, published in major academic and technical journals, and have extensive experience in designing and implementing technical assistance and training programs. Andrew Young School faculty have been active in policy reform in over 40 countries around the world. Our technical assistance strategy is not merely to provide technical prescriptions for policy reform, but to engage in a collaborative effort with host governments and donor agencies to identify and analyze the issues at hand, arrive at policy solutions, and implement reforms.

ICePP specializes in four broad policy areas:

- Fiscal policy (e.g., tax reforms, public expenditure reviews)

- Fiscal decentralization (e.g., reform, intergovernmental transfer systems, urban finance)

- Budgeting and fiscal management (e.g., local, performance-based, capital, and multiyear budgeting)

- Economic analysis and revenue forecasting (e.g., micro-simulation, time series forecasting)

For more information about our technical assistance activities and training programs, please visit our website at http://icepp.gsu.edu or contact us by email at paulbenson@gsu.edu. 


\title{
Performances in COVID-19 Management Across Countries: Do Subnational Finances Matter?
}

\author{
Simanti Bandyopadhyay, ${ }^{1}$ Sujana Kabiraj, ${ }^{2}$ and Subrata Majumder ${ }^{3}$
}

May 2021

\begin{abstract}
The spread of the COVID-19 pandemic has emphasized the role of governments in a public health emergency not only in developing countries, but in the developed world as well. This paper has a two-fold objective. First, we investigate the efficiency of COVID management using state-level data from three of the worst affected countries, USA, India, and Mexico, in three time periods in the pre-vaccine phase. Next, we explore the extent to which state government financial, sociodemographic, and governance indicators can explain the difference in efficiency. We use a two-stage non-parametric method. The first stage comprises of meta frontier analysis to derive efficiency scores for each state. We analyze state governments in these countries together (grand frontier) and separately (group frontier). Overall, grand efficiency continuously increased from August to November 2020. The grand efficiency scores of Mexico and the USA gradually increased on 3rd October and 29th November 2020. The results reflect that the USA was holding the leading position in terms of COVID-19 pandemic management at that time. In terms of group efficiency, American states performed consistently well with respect to their own country as well as other countries. However, if we compare the grand and group efficiency scores of all three countries, we find that states in India and Mexico performed well in their own countries but worse than USA states in terms of the global scenario. The states of India always performed better within their own country than the states of the other two countries. The second analytical stage uses an exploratory median analysis to investigate the impact of different indicators on efficiency. State finance variables are positively associated with the grand efficiency score for all three time periods, while the association is negative for the expenditures to own revenue ratio and expenditures to total revenue ratios, debt ratios with respect to different fiscal indicators, and percentage of health expenditure over total expenditures and GSDP. These patterns are less consistent among countries when we look at group efficiency over time. We find a positive association of per capita total revenue with group efficiency scores for all countries over all time periods.
\end{abstract}

\footnotetext{
${ }^{1}$ Associate Professor of Economics and Public Policy, Shiv Nadar University, India. Corresponding author, email: simantib@gmail.com

${ }^{2}$ Assistant Professor of Economics, University of Wisconsin - Stevens Point, USA

${ }^{3}$ Assistant Professor of Economics, Sundarban Mahavidyalaya, India
} 


\section{Introduction and Literature}

The COVID-19 pandemic has been different to any other disaster the world has

experienced in the last century. COVID-19 has spread in 214 countries and territories within a

few months, making it one of the worst pandemics in history. During the pandemic, all levels of world governments have operated under extreme uncertainty and strong measures of lockdowns and containments have been taken in almost all countries. Despite all the efforts towards prevention and control, as of March 29, 2021 around 127 million cases have been confirmed and it has claimed the lives of approximately 2.79 million people. Although conventional disaster relief tools have been rendered inadequate due to the vast, universal, and unpredictable spread of the pandemic, it is incontrovertible that government bodies still play a significant role in managing the disaster.

In a multi-tier government set up, each tier (central, state, and local) plays a significant role in managing disasters and emergencies in all countries across the globe. Carter (2008) categorizes disaster management systems into three parts: preparedness, response, and recovery, and recognizes that the system utilizes the total extent and depth of an existing government structure of a country including central, state (or equivalent), and local (county/city/village/etc.) government bodies. Since the government structure is pre-defined and relatively permanent in a country, it is utilized as the backbone of disaster management preparedness and activities. However, the roles of different tiers of governments may vary across countries. ${ }^{1}$

\footnotetext{
1 According to Col (2007), in the United States, state and local governments are generally responsible for all phases of disaster management with assistance from the federal government agencies like FEMA (Federal Emergency Management Agency). In India, the disaster management structure underwent a paradigm shift in 2005, after the Disaster Management Act (2005) was passed. The Act creates national, state, and district level disaster management authorities who play proactive roles in prevention, mitigation, and preparedness-driven approaches to minimize the loss of human lives, livelihoods, and economic properties in case of natural disasters (Singh, Pandey, and Mina, 2019). The federal government in Mexico has created different kinds of catastrophe bonds and natural disaster funds (Fonden) to deal with natural disasters (Buhler, 2018). According to the Law on Federal Public Administration and the General Law on National Property in Mexico, every government institution must have insurance against natural disasters to protect its property and infrastructure. In addition, beginning in 2017, all 31 states and Mexico City are mandated to create their own reserves to fight disasters (Buhler, 2018).
} 
Central governments have generally committed to provide substantial aids to mitigate the devastating health and socioeconomic impact of the pandemic. If we go through the primary measures taken by the central governments in some of the worst affected countries viz. USA, India, and Mexico, we find that the federal government in the USA has passed several acts to fight the direct and socioeconomic effects of the COVID-19 crisis. $^{2}$ An estimated US $\$ 2.3$ trillion (around 11\% of GDP) Coronavirus Aid, Relief and Economy Security Act ("CARES Act") was passed in March 2020, along with a $\$ 483$ billion Paycheck Protection Program and Health Care Enhancement Act, a $\$ 8.3$ billion Coronavirus Preparedness and Response Supplemental Appropriations Act, and a US\$192 billion Families First Coronavirus Response Act. The acts include expenditures for virus testing; transfers to states for Medicaid funding; funds for development of vaccines, therapeutics, and diagnostics; support for the Centers for Disease Control and Prevention (CDC)'s responses; and grants for hospitals as a direct measure to fight the COVID-19 pandemic. To mitigate socioeconomic disaster due to the pandemic, the acts also include one-time tax rebates to individuals; expansion of unemployment benefits; prevention of corporate bankruptcy by providing loans; forgiveness of Small Business Administration loans and guarantees to help small businesses that retain workers; transfers to state and local governments; and international assistance.

India's fiscal support measures can be divided into two broad categories: (i) direct spending (about 1.7 percent of GDP, approximately $\$ 50$ billion) ${ }^{3}$; and (ii) below-the-line measures designed to support businesses and increase credit provision to several sectors (about

\footnotetext{
${ }^{2}$ The central government intervention data for all three countries has been used until November 2020. A more updated account can be found at Covid 19 Policy Response article by IMF (https://www.imf.org/en/Topics/imf-andcovid19/Policy-Responses-to-COVID-19\#I)

${ }^{3}$ All calculations for Mexico and India are done using 2019 GDP data for the respective countries and rupee to dollar exchange rate, and peso to dollar exchange rate of 2021.
} 
4.9 percent of GDP, approximately $\$ 140$ billion). The key direct-spending measures are the transfer of cash and in-kind (food; cooking gas) support to lower-income households, insurance coverage for workers in the healthcare sector, and wage support and employment provision to low-wage workers. An additional $\$ 2.04$ billion (about 0.1 percent of GDP) will be allocated to healthcare infrastructure. Moreover, several measures have also been announced to ease the tax compliance burden. Apart from this, a public charitable trust under the name of 'Prime Minister's Citizen Assistance and Relief in Emergency Situations Fund' (PM CARES Fund) has been set up to deal with any kind of emergency.

Fiscal policy to fight the COVID-19 pandemic in Mexico has had a four-fold agenda: (i) ensuring sufficient financial resources to Ministry of health; (ii) supporting households and firms through the pandemic by providing housing credits and personal loans (approximately $\$ 1.9$ billion, 0.15 percent of GDP) at a lower interest rate, and a deferral program of monthly payments (approximately $\$ 25.1$ million, 0.002 percent of GDP); (iii) boosting credit and strengthening liquidity and health of financial markets by lending to firms and workers in both formal and informal sectors, and injecting liquidity through development banks (approximately $\$ 3.23$ billion, 0.25 percent of GDP); and (iv) acceleration of tender processes for public expenditure. Additionally, further resources have been allocated to increase social spending related to infrastructure, security, education, and other areas (approximately, $\$ 2.5$ billion, 0.2 percent of GDP).

Even a highly active central government cannot handle a crisis of this proportion alone. Recognizing the role of subnational governments in disaster management, which is acknowledged if not well-researched by scholars in disaster management literature, we identify the potential in the performance of state governments in managing the COVID-19 crisis. The 
literature is scant and sporadic in this area. Bandyopadhyay and Roy Chowdhury (2020) find that fiscal health has a positive role to play in managing the COVID-19 pandemic using state-level data of fatality and recovery in India for March 2020. According to Dupré et al. (2020), there have been highly differentiated impacts of COVID-19 on subnational finance in different countries and the main determinants of such varying effects are the degree of decentralization, sensitivity towards economic fluctuations, fiscal flexibility to adjust revenues and expenditures, fiscal health, and the efficiency and scope of support from higher levels of government. Nemec and Špaček (2020) look at the problem from a different angle. They explore the impact of COVID-19 on intergovernmental relations and local government finance in Czechia and Slovakia. They find that the fiscal imbalances in those two countries at the municipal level are not proportional to the situation at the central government and that local government finances may face issues with service delivery due to inadequate response to COVID-19 from the central government. Dutta and Fischer (2020) argue that governance has a substantial role to play in the trajectory of the COVID-19 pandemic.

So far, there has not been any study, theoretical or empirical, exploring the role of state finances and other indicators to both act as catalysts in implementing central government measures and add new dimensions to drive the success of COVID-19 crisis management. Granted, our work is closest to Bandyopadhyay and Roy Chowdhury (2020) and has certain overlaps with Dupré et al. (2020). We also investigate the governance angle of the story, a context similar to Dutta and Fischer (2020). To the best of our knowledge, however, this is the first attempt to address the state fiscal element of these issues in a structured, rigorous, empirical framework. In this paper, we explore the role of state finance and attempt to establish its importance as a factor explaining the efficiency in management of the COVID-19 crisis in the 
pre-vaccine stage. We choose three countries: the USA, India, and Mexico, which are amongst the worst affected countries by the pandemic.

We intend to address several research questions related to the efficiencies of COVID-19 management across countries, questions that can be laid out in two layers. The first layer deals with country-specific and overall efficiencies and their behavior across time: How can we assess the efficiency of performance in COVID-19 management? How do these efficiencies vary across countries? Are the countries becoming more efficient with experience? The second layer of questions delves deeper into establishing the role of state-level indicators in explaining the performances, overall, within each country and in inter-country comparisons: What are the important determinants of these efficiencies? Can state indicators explain efficiencies in COVID management in a country? In state indicators, we include mostly indicators related to state finances; sociodemographic and governance indicators are also considered. The study is based on data on the three highly-affected countries mentioned above. Although early cases in all three countries were confirmed in late January or early February, the true outbreak started in March in the USA and in June in both India and Mexico. We consider deaths and recoveries after a few months in the pandemic. ${ }^{4}$

The paper is organized as follows: Section 2 describes the methodology with the data and variables; Section 3 spells out the results; and Section 4 concludes the paper.

\section{Methodology, Data and Variables}

We use a two-stage method to address our research questions as laid out in the two layers described above. In the first stage, we derive the efficiency scores for the COVID management

\footnotetext{
${ }^{4}$ We use data for all three countries between August to November. All three countries suffered a substantial number of cases, deaths, recoveries until the initial period and also during the period of our study.
} 
for each country as a whole and at the state level. We envisage COVID-19 management as a simple production process, with 'inputs' like doctors, paramedics, and hospital beds leading to recoveries or deaths, which are treated as the 'outputs' of the process. We attempt a meta frontier analysis using subnational level data on these inputs and outputs. We derive the efficiency scores for each country as a whole and for each state of a country. This way, we can compare efficiencies in COVID-19 management across the states within a country and across countries. We also compare the score of a state in its 'group' (that is, relative to the other states in the country it is located) and with the states of all analyzed countries together. This yields insights into the performance of a particular state in its own country vis a vis those of all other included countries taken together.

In the second stage, we study the role of state indicators in explaining differences in efficiency in COVID-19 management. Amongst state indicators, we are particularly interested in finding whether state finances can play an active role in COVID-19 management. We also include some sociodemographic, development, and governance indicators at the state level to understand these factors' roles.

\section{Stage 1: Nonparametric DEA}

The Data Envelopment Analysis (DEA) technique first evolved from the school of mathematical programming. The famous economist Koopmans (1951) recognized the connection between the problem of the existence of non-negative prices and quantities in a Walras-Cassel economy and the mathematical programming problem of optimizing an objective function subject to a set of linear inequality constraints. He defined a point in the commodity space as efficient whenever an increase in the net output of one good required a decrease in that of some other good. In view of its obvious similarity with the notion of Pareto optimality, this definition is known as the Pareto-Koopmans condition for Technical Efficiency (TE). In the same year, 
Debreu (1951) introduced the concept of the coefficient of resource utilization as a measure of TE for the economy as a whole (from the point of view of the cost of resources) and interpreted any deviation of this measure from unity as a deadweight loss for the society on account of the inefficient utilization of resources. The measures of efficiency developed by Farrell (1957) expressed a close link with the notion (in axiomatic production theory) of radial contraction of inputs/expansion of outputs from an observed point to the frontier, i.e., the efficiency of a firm reflects its ability to use the inputs in optimal proportion, given their respective prices, or to achieve the maximum level of output attainable by the state of technology. In his pioneering 1957 work, Farrell assumed constant returns to scale (CRS) of technology in production. Hoffman (1957) pointed out that the dual simplex method, an algorithm to solve a linear programming (LP) problem, could be applied to obtain Farrell's measure of efficiency. This turned out to be an important pragmatic suggestion and was adopted by Farrell himself in his later work with Fieldhouse (1962), where the case of increasing returns to scale was also incorporated. After that, in DEA literature Charnes, Cooper, and Rhodes (1978) contributed their crucial work, known as the CCR model. Their model can convert fractional programming into a linear programming by selecting suitable weights (which is nothing but the virtual prices of inputs and outputs). Later, they wrote two more papers in 1979 and 1981 in which a generalized DEA in a multiple-output/multiple-input framework. In those papers, they argued that the imposition of a CRS structure for production technology implicitly assumes that producing units operate on optimal scales. As different firms operate in different market structures, with different externalities and financial restrictions, therefore this kind of model is always not always applicable in every situation. For that reason, in relaxing the CRS assumption the variable returns to scale (VRS) model was developed by Banker, Charnes, and Cooper (1984). This is known as 
the BCC model, which can decompose technical inefficiency and scale inefficiency by defining and estimating the former at a given scale of operation under the assumption of a unique optimum (Maindiratta, 1990).

\section{Meta Frontier Analysis}

In general frontier analysis, it is assumed that all the observed units have identical technology. This may not always be realistic, as different units may have access to different production technologies. A variety of geographical, institutional, or other factors may give rise to such a situation. Construction of a general frontier for all units may give an inaccurate estimation of the efficiency of a unit. A way to address this problem of non-availability of all techniques to all firms is meta frontier analysis as proposed in Battese and Rao (2002) and Battese, Rao, and O’Donnell (2004). In this analysis, one constructs separate production possibility sets (and hence separate production frontiers) for separate groups of firms, with each such set being defined on the basis of observations on inputs and outputs of the firms belonging to the group in question, which is then used to measure a firm's within-group technical efficiency. In meta vs. group frontier analysis, the firms are first classified into different regions/groups based on certain criteria and the group-specific frontiers are constructed to estimate the efficiency of the firms against the group frontier. Further, a global or grand frontier which is indicated as a meta frontier is also constructed by considering all firms in the sample; the efficiency of the firm is also calculated against the grand frontier.

When we face heterogeneities in technologies used by sub-groups of decision-making units (DMUs), we can expect the existence of different operational technologies within these groups. This necessitates that we compare the performance of each DMU within its respective group using a group-specific technology. Therefore, we compare the performance of DMUs with respect to their group-level technology (group frontier) relative to their performance with respect 
to the industry level technology (meta frontier). The meta frontier, which is called a grand frontier, is the envelope of all the group frontiers. This can be illustrated using the diagram given below (Figure 1). We can see that the meta frontier $\mathrm{MM}^{\star}$ is an envelope of the three group frontiers: $\mathrm{g} 1 \mathrm{~g} 1^{`}, \mathrm{~g} 2 \mathrm{~g} 2^{\star}$, and $\mathrm{g} 3 \mathrm{~g} 3^{\star}$. The estimate of the gap between group frontier and meta frontier can help us identity the gap between the technologies used within a specific group and the technology used in the entire industry.

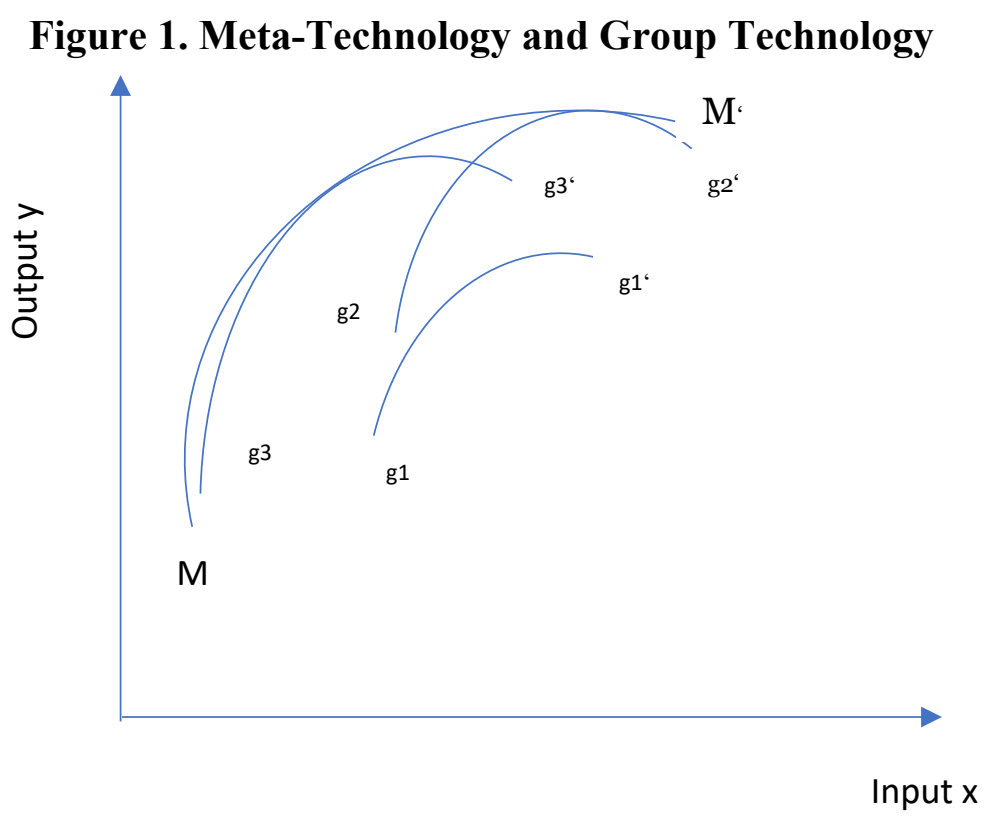

\section{The Meta Frontier}

Let $\mathrm{y}$ and $\mathrm{x}$ be real output and input vectors of the dimension (C X 1) and (D X 1), respectively. The meta-technology set contains all input-output combinations that are technologically feasible. Formally, we write

$$
T=\{(x, y): x \geq 0 ; y \geq 0 ; x \text { can produce } y\}
$$

With this meta-technology, we have a set of input and output sets. The output set can be defined for any input vector $\mathrm{x}$ as:

$$
P(x)=\{y:(x, y) \in T\}
$$

The boundary of this output set is called the output meta frontier. 


\section{The Group Frontiers}

Some of the DMUs face different sub-technologies which lead to different production possibilities for them. We can divide all DMUs into $G$ groups $(G>1)$. The different environmental constraints may hinder the DMUs choice from all the technology feasible inputoutput combinations in the meta-technology set T. We, therefore, have a different group-specific technology set available to DMUs in the $g^{\text {th }}$ group represented by:

$$
T^{g}=\{(x, y): x \geq 0: y \geq 0 ; x \text { can be used by DMUs in group } g \text { to produce, } y\}
$$

This $g$ group specific technology can be represented by the following output sets:

$$
P^{g}(x)=\left\{y:(x, y) \in T^{g}\right\}, g=1,2,3 \ldots . G .
$$

The boundaries of the group specific output sets are called group frontiers. Figure 1 above gives a visual representation of these sets.

\section{Estimation of Technical Efficiency}

In this section, we describe the estimation technique applied to measure the technical efficiency score of a firm. The assumptions are (a) all the observed input output bundles are feasible; (b) the production possibility set is convex, implying that given a set of $N$ feasible inputoutput bundles, any weighted average of these $N$ input bundles can produce the same weighted average of the corresponding $N$ output bundles; and (c) any input or output is freely disposable. The DEA attempts to generate the production frontier from the observed data without making any specific assumption regarding the functional form of the production function.

Suppose there are $N$ firms in the system and we consider the $t^{\text {th }}$ firm. The input output bundle of that firm is: $x^{t}=\left(x_{1 t}, x_{2 t}, \ldots, x_{n t}\right)$ and $y^{t}=\left(y_{1 t}, y_{2 t}, \ldots, y_{m t}\right)$. To obtain the value of total inputs used and total outputs generated by a firm, one needs appropriate virtual prices $u_{i t}$ and $v_{j t}$ for inputs and outputs respectively. The total value of inputs used by the $t^{\text {th }}$ firm would be $\sum_{i=1}^{n} u_{i t} x_{i t}$ and the total value of outputs produced by $t^{t h}$ firm would be $\sum_{j=1}^{m} v_{j t} y_{j t}$. The 
average productivity of the firm $t$ would be $A P_{t}=\frac{\sum_{j=1}^{m} v_{j t} y_{j t}}{\sum_{i=1}^{n} u_{i t} x_{i t}}$.

To give virtual prices the status of shadow prices, one needs to implicitly assume a perfectly competitive market structure, leaving no scope for supernormal profit. Hence, the production relation must satisfy the constraint stated as $\sum_{j=1}^{m} v_{j t} y_{j t} \leq \sum_{i=1}^{n} u_{i t} x_{i t} \forall t$ along with non-negativity restriction on shadow prices. So, the intended programming problem would be:

Model 1: Max: $A P_{t}=\frac{\sum_{j=1}^{m} v_{j t} y_{j t}}{\sum_{i=1}^{n} u_{i t} x_{i t}}$

Subject to: $\sum_{j=1}^{m} v_{j t} y_{j t} \leq \sum_{i=1}^{n} u_{i t} x_{i t}$ and $\forall t=1,2, \ldots, N$ and $u_{i t}, v_{j t} \geq 0$

Two problems may immediately be recognized with respect to this formulation. Firstly, by virtue of the profit constraint the objective function would be a fraction. Moreover, the system is homogeneous of degree zero in prices and therefore, if $u_{i t}$ 'sand $v_{j t}$ 'squalify as shadow prices, so would be $\lambda u_{i t}$ 's and $\lambda v_{j t}$ 's. To handle both these problems simultaneously, a price normalization constraint can be incorporated which will change the programming problem as:

Model 2: Max: $\sum_{j=1}^{m} p_{j t} y_{j t}$

Subject to: $\sum_{j=1}^{m} p_{j t} y_{j t}-\sum_{i=1}^{n} w_{i t} x_{i t} \leq 1 \forall t=1,2, \ldots, N$ and

$$
\sum_{i=1}^{n} w_{i t} x_{i t}=1, w_{i t}, p_{j t} \geq 0 \forall t=1,2, \ldots, N
$$

This is a standard Linear Programming Problem and here $w_{i t}=\lambda u_{i t}$ and $p_{j t}=\lambda v_{j t}$ with $\lambda>0$. Since the constraints apply to every firm including firm $t$, the maximum value of the objective function would be $\mathrm{AP}_{\mathrm{t}}=1$ (Raa, 2009).

Therefore, the dual of Model 2 will be:

\section{Model 3: Min: $\theta$}

Subject to: $\sum_{t=1}^{N} \lambda_{t} y_{j t} \geq y_{j t} ; \forall j=1,2, \ldots, m$ and $\sum_{t=1}^{N} \lambda_{t} x_{i t} \leq \theta x_{i t} ; \forall i=1,2, \ldots, n$ and $\lambda_{t} \geq 0 ; \forall t=1,2, \ldots, N$

Where: $\theta$ is free.

From Model 3, one can estimate $\theta$, which is nothing but the input oriented technical 
inefficiency score of $t^{t h}$ firm under CRS assumption. Again, if we define $\varphi=\frac{1}{\theta}$ and $\mu_{t}=\frac{\lambda_{t}}{\theta}$ then minimization of $\theta$ is equivalent with maximization of $\varphi$. In term of redefined variables, the LP problem (Model 3) now becomes

Model 4: Max: $\varphi$

Subject to: $\sum_{t=1}^{N} \mu_{t} y_{j t} \geq \varphi y_{j t} ; \forall j=1,2, \ldots, m$ and $\sum_{t=1}^{N} \mu_{t} x_{i t} \leq x_{i t} ; \forall i=1,2, \ldots, n$ and $\mu_{t} \geq 0 ; \forall t=1,2, \ldots, N$

Where: $\varphi$ is free.

The score generated from the expression $\frac{1}{\varphi}$ is nothing but the output oriented technical efficiency of the $t^{\text {th }}$ firm under CRS. These two models consist of the first-generation model of efficiency score measurement known as CCR model. The (in)efficiency measurement with additional constraint $\sum_{t=1}^{N} \lambda_{t}=1$ in Model 3 and $\sum_{t=1}^{N} \mu_{t}=1$ in Model 4 express extended version of CCR model known as BCC model which considers the VRS assumption instead of CRS assumption.

In this paper, we modify the standard model for output-oriented TE (Model 4) by replacing the assumption of 'free disposability of all outputs' to 'free disposability of good output and weak disposability of bad output'. Therefore, specifically in this paper, the model which is finally considered is

Model 5: Max: $\tilde{\varphi} \tilde{\varphi}$

Subject to: $\sum_{t=1}^{N} \mu_{t} y_{j t} \geq \tilde{\varphi} y_{j t} ; \forall j$ Good Outputs and

$$
\begin{aligned}
& \sum_{t=1}^{N} \mu_{t} y_{k t}=\alpha \tilde{\varphi} y_{k t} ; \forall k \text { Bad Outputs and } \\
& \sum_{t=1}^{N} \mu_{t} x_{i t} \leq x_{i t} ; \forall i=1,2, \ldots, n \sum_{t=1}^{N} \mu_{t} x_{i t} \leq x_{i t} ; \forall i=1,2, \ldots, n \text { and } \\
& \sum_{t=1}^{N} \mu_{t}=1 \text { and } \mu_{t} \geq 0 ; \forall t=1,2, \ldots, N
\end{aligned}
$$

Where: $\tilde{\varphi}$ is free $\& 0 \leq \alpha \leq 1$

The score generated from the expression $\frac{1}{\tilde{\varphi}}$ is nothing but the output oriented technical efficiency of the $t^{t h}$ firm under VRS. We finally solve the model putting $\alpha=1$, as it can be shown that this does not alter the optimal value of the objective function (Färe et al., 1985). 
We repeat the process of estimation twice applying Model 5: once with state data of all analyzed countries together (generating efficiencies for the grand component) and once with states of a particular country separately (generating efficiencies for the group component).

\section{Variables and Data}

To estimate the technical efficiency, here three inputs and two outputs are taken. The total numbers of doctors, paramedics, and hospital beds are considered as inputs. The total number of recoveries is considered the good output and total number of deaths is considered the bad output. The data on these input-output variables are collected at the state level ${ }^{5}$ for three countries (India, Mexico, and the USA). Accordingly, 31 states are taken from India, 32 states from Mexico and 50 states from the USA for our dataset. ${ }^{6}$ The summary statistics for output are given in Table 1. The summary statistics of inputs are given in Table $2 .{ }^{7}$ We have collated data from different sources for different classes of data. Also, we have considered three dates, viz. until August 27, 2020, until October 2, 2020 and until November 29, 2020, to collect the data.

For the two outcome variables for measuring the performances of the states/regions in COVID-19 management: cumulative deaths and recoveries at the end of each of the three dates mentioned above, the data for Indian states have been taken from the Ministry of Health and Family Welfare website where data for active cases, deaths, and discharged patients are provided and updated regularly. US state-level COVID-19 data is collected from the Worldometer website. The data for Mexico is taken from the Johns Hopkins University real time data website.

\footnotetext{
5 In our paper, each state is considered as a decision-making unit (DMU) in case of COVID-19 pandemic management.

${ }^{6}$ Note that Washington, D.C., is excluded despite being a federal district (state equivalent) due to lack of data. In India, we have taken the major states and not the special category states, as the special category states have different fiscal arrangements with the central government; this is a standard practice for Indian states.

7 Here, in our efficiency estimation model, for three time periods the values of all inputs in the input set are same. Only the values of output variables differ from time to time.
} 
We have used the number of doctors, paramedics, and hospital beds to measure the preparedness of the states in managing COVID-19 pandemic. The data for number of doctors and paramedics are collected from the occupational employment statistics of BLS (Bureau of Labor Statistics) for the USA, while the same is collected from the National Health Profile 2019 (14 ${ }^{\text {th }}$ issue) for India. The number of hospital beds is collected from the AHA annual survey (2018) for the USA and from Kapoor et al. (2020) for India. In Mexico, private sector health statistics are collected from the National Institute of Statistics and Geography (INEGI) website and the public sector health indicators are collected from the Government of Mexico (Gobierno de México) website.

Table 1: Summary Statistics: Status of Outputs (COVID-19 Deaths and Recoveries)

\begin{tabular}{|c|c|c|c|c|c|c|c|}
\hline & \multirow[b]{2}{*}{ Statistics } & \multicolumn{2}{|c|}{ AUG-27-2020 } & \multicolumn{2}{|c|}{ OCT-03-2020 } & \multicolumn{2}{|c|}{ NOV-29-2020 } \\
\hline & & Recovery & Death & Recovery & Death & Recovery & Death \\
\hline \multirow{8}{*}{ IND } & Obs. & 31 & 31 & 31 & 31 & 31 & 31 \\
\hline & Mean & 83,098 & 1,981 & $1,77,085$ & 3,274 & $2,82,944$ & 4,395 \\
\hline & Median & 43,757 & 448 & $1,11,712$ & 912 & $1,87,969$ & 1,680 \\
\hline & $\mathrm{SD}$ & $1,19,866$ & 4,362 & $2,44,030$ & 6,937 & $3,58,503$ & 8,620 \\
\hline & Skewness & 2 & 4 & 2 & 4 & 2 & 4 \\
\hline & Kurtosis & 8 & 20 & 9 & 21 & 9 & 21 \\
\hline & Min. & 500 & 0 & 1,772 & 0 & 3,425 & 5 \\
\hline & Max. & $5,31,563$ & 23,444 & $11,34,555$ & 37,758 & $16,76,564$ & 46,986 \\
\hline \multirow{8}{*}{ MEX } & Obs. & 32 & 32 & 32 & 32 & 32 & 32 \\
\hline & Mean & 10,250 & 1,890 & 19,937 & 2,465 & 25,414 & 3,296 \\
\hline & Median & 8,428 & 1,233 & 15,174 & 1,697 & 18,144 & 2,488 \\
\hline & SD & 11,211 & 2,065 & 20,917 & 2,487 & 28,708 & 3,272 \\
\hline & Skewness & 3 & 3 & 3 & 3 & 4 & 3 \\
\hline & Kurtosis & 13 & 11 & 12 & 10 & 17 & 10 \\
\hline & Min. & 1,321 & 313 & 4,028 & 485 & 4,362 & 667 \\
\hline & Max. & 59,545 & 10,159 & $1,08,944$ & 12,252 & $1,61,039$ & 15,588 \\
\hline \multirow{7}{*}{ USA } & Obs. & 50 & 50 & 50 & 50 & 50 & 50 \\
\hline & Mean & 64,873 & 3,607 & 93,907 & 4,158 & $1,56,836$ & 5,304 \\
\hline & Median & 33,328 & 1,642 & 51,864 & 2,099 & 87,248 & 3,145 \\
\hline & SD & 95,596 & 5,673 & $1,30,441$ & 6,035 & $1,89,010$ & 6,769 \\
\hline & Skewness & 3 & 3 & 3 & 3 & 2 & 2 \\
\hline & Kurtosis & 12 & 16 & 11 & 12 & 10 & 9 \\
\hline & Min. & 1,396 & 37 & 1,622 & 53 & 2,494 & 67 \\
\hline
\end{tabular}




\begin{tabular}{|l|l|r|r|r|r|r|r|} 
& Max. & $4,95,569$ & 32,794 & $6,95,684$ & 32,994 & $9,87,717$ & 34,512 \\
\hline \multirow{5}{*}{ ALL } & Obs. & 113 & 113 & 113 & 113 & 113 & 113 \\
\cline { 2 - 7 } & Mean & 54,404 & 2,675 & 95,779 & 3,436 & $1,54,215$ & 4,486 \\
\cline { 2 - 7 } & Median & 14,632 & 1,084 & 29,527 & 1,530 & 51,333 & 2,376 \\
\cline { 2 - 8 } & SD & 93,356 & 4,589 & $1,64,289$ & 5,572 & $2,44,159$ & 6,604 \\
\cline { 2 - 8 } & Skewness & 3 & 4 & 4 & 4 & 3 & 4 \\
\cline { 2 - 8 } & Kurtosis & 14 & 22 & 19 & 21 & 17 & 20 \\
\cline { 2 - 8 } & Min. & 500 & 0 & 1,622 & 0 & 2,494 & 5 \\
\cline { 2 - 8 } & Max. & $5,31,563$ & 32,994 & $11,34,555$ & 37,758 & $16,76,564$ & 46,986 \\
\hline
\end{tabular}

Table 2: Summary Statistics of Input Variables (Doctors, Paramedics, and Hospital Beds)

\begin{tabular}{|c|c|c|c|c|c|c|c|}
\hline & Statistics & Doctors & $\begin{array}{l}\text { Per } \\
\text { Capita } \\
\text { Doctors } \\
\end{array}$ & Paramedics & $\begin{array}{l}\text { Per Capita } \\
\text { Paramedics }\end{array}$ & $\begin{array}{l}\text { Hospital } \\
\text { Beds }\end{array}$ & $\begin{array}{l}\text { Per Capita } \\
\text { Hospital } \\
\text { Beds } \\
\end{array}$ \\
\hline \multirow{8}{*}{ IND } & Obs. & 31 & 31 & 31 & 31 & 31 & 31 \\
\hline & Mean & 35770 & 0.001 & 203069 & 0.005 & 60958 & 0.002 \\
\hline & Median & 15038 & 0.001 & 88462 & 0.005 & 26496 & 0.002 \\
\hline & $\mathrm{SD}$ & 45273 & 0.001 & 233342 & 0.004 & 77048 & 0.001 \\
\hline & Skewness & 1 & 0.699 & 1 & 1.243 & 2 & 0.674 \\
\hline & Kurtosis & 4 & 2.442 & 3 & 5.229 & 5 & 2.778 \\
\hline & Min. & 74 & 0.000 & 922 & 0.000 & 1790 & 0.000 \\
\hline & Max. & 173384 & 0.002 & 706732 & 0.018 & 281402 & 0.004 \\
\hline \multirow{8}{*}{ MEX } & Obs. & 32 & 32 & 32 & 32 & 32 & 32 \\
\hline & Mean & 8262 & 0.002 & 11317 & 0.003 & 3850 & 0.001 \\
\hline & Median & 6550 & 0.002 & 9010 & 0.003 & 2862 & 0.001 \\
\hline & SD & 7910 & 0.001 & 10559 & 0.001 & 3969 & 0.000 \\
\hline & Skewness & 2 & 3.088 & 3 & 3.056 & 3 & 3.048 \\
\hline & Kurtosis & 6 & 13.407 & 11 & 15.028 & 11 & 15.280 \\
\hline & Min. & 1823 & 0.001 & 2540 & 0.002 & 804 & 0.001 \\
\hline & Max. & 33973 & 0.005 & 54902 & 0.006 & 20363 & 0.002 \\
\hline \multirow{8}{*}{ USA } & Obs. & 50 & 50 & 50 & 50 & 50 & 50 \\
\hline & Mean & 18030 & 0.003 & 5199 & 0.001 & 16248 & 0.003 \\
\hline & Median & 11899 & 0.003 & 3790 & 0.001 & 12060 & 0.003 \\
\hline & $\mathrm{SD}$ & 20836 & 0.001 & 5064 & 0.000 & 16469 & 0.001 \\
\hline & Skewness & 2 & 0.994 & 2 & 0.284 & 2 & 0.845 \\
\hline & Kurtosis & 10 & 3.805 & 5 & 2.383 & 6 & 3.729 \\
\hline & Min. & 1201 & 0.002 & 560 & 0.000 & 1617 & 0.002 \\
\hline & Max. & 110335 & 0.004 & 21990 & 0.001 & 71031 & 0.005 \\
\hline
\end{tabular}




\section{Stage 2: Exploratory Nonparametric Median Group Classification Analysis}

In this stage, we analyze the variations of the 113 grand technical efficiency scores (state level) with respect to some state finance related factors and with some sociodemographic and development indicators. Using these variables as explanatory factors, we apply an Exploratory Nonparametric Median Group Classification Analysis ${ }^{8}$ to explore the variation of grand TE scores. After that, the same technique has also been applied to analyze the variation of country specific Group Technical Efficiency Scores (state level) for India, Mexico, and the USA separately.

First, for each explanatory variable, we calculate the median. Then, for each explanatory variable, we classify the technical efficiency scores between two groups. Explanatory variables values are sorted into these two groups for each explanatory variable, denoted as Lower than Median Group (LMG) and Higher than Median Group (HMG), according to the variable's median value. After that, we calculate the average of the TE scores of the two groups (LMG and HMG) for each explanatory variable. Then we compare the values of the calculated means (of the TE Scores) between the two groups for each explanatory variable. Finally, we explore and thoroughly analyze the change of average TE scores of the two groups for each explanatory variable. We seek patterns of relationships with the variables explaining efficiencies, comparing the results of the three time periods mentioned above. If the same monotonic 'increase-increaseincrease' or 'decrease-decrease-decrease' pattern comprising the three time periods appears, that indicates that the variable has a clear role in explaining variations in efficiency.

\footnotetext{
${ }^{8}$ We also tested the standard Confirmatory Parametric Methods (like OLS and Probit/Tobit Regression) to find out the exact causes of the variation of generated TE Scores. However, we failed to get conclusive results from both OLS and Probit/Tobit Regression.
} 


\section{Variables and Data}

The variations in the efficiency scores for the grand frontier have been explained by 31 variables. The variation of group TE scores has also been explained with respect to additional variables subject to their availability. All the financial variables are expressed in USD. Table 3 lists these variables.

For the USA, the state finance data are collected from the US Census Bureau. The data for India are taken from the Subnational Finance Budget Report published by the Reserve Bank of India. In Mexico, the state finance data are taken from National Institute of Statistics and Geography (INEGI). We use total revenue, own revenue, total expenditure, health expenditure, hospital expenditure, and public debt data to indicate fiscal health at the state level.

The state level gross domestic product data is collected from the Bureau of Economic Analysis in the USA, the Ministry of Statistics and Programme Implementation (MoSPI) in India, and INEGI in Mexico. Each country defines its calamity relief fund (or parallel concept) somewhat differently. Accordingly, we recognized rainy-day fund (also known as budget stabilization fund) data as a proxy for calamity relief in the USA. A rainy-day fund allows a state to set aside surplus revenue for use during unexpected deficits. The data are taken from the Pew Charitable Trusts. For India, we use the disaster management fund data from the $15^{\text {th }}$ Finance Commission Report. In Mexico, we use the Natural Disaster Fund (FONDEN) data taken from Buhler (2018).

Another indicator to gauge efficiency is state level governance indicators. For USA, state level governance indicators are not readily available, so, we used budget efficiency indicators as a proxy for governance. For India, we used state level governance indicators provided by Public Affairs Indicators. The governance indicator data for Mexico are taken from the World Justice 
Project's Mexico States Rule of Law Index 2018. The data for the percentages of population over 65 years of age, working, and literate are from the US Census Bureau, BLS, and World Population Review, respectively, for the USA. For India, the same has been collected from projections on Census 2011 data. For Mexico, the population and working population data is taken from National Survey of Occupation and Employment (ENOI 2017) and the literacy rate is taken from INEGI. Although data from different years are used for these indicators, we believe such percentages change slowly over time and thus should not bias our results.

Table 3: Variables Used in Stage 2 to Explain Variations in Efficiency Scores in Stage ${ }^{9}$

\begin{tabular}{|c|c|c|}
\hline \multicolumn{2}{|c|}{\begin{tabular}{l|l} 
Variables \\
\end{tabular}} & Abbreviations \\
\hline \multirow{26}{*}{ 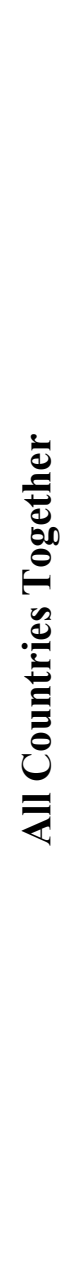 } & 1 Per Capita Own Revenue & pc_own_rev \\
\hline & 2 Per Capita Total Revenue & pc_tot_rev \\
\hline & 3 Per Capita Total Expenditure & pc tot exp \\
\hline & 4 Per Capita Health Expenditure & pc_health_exp \\
\hline & 5 Per Capita GSDP & pc_gsdp \\
\hline & 6 Perc. of Health Expenditure Over Total Expenditure & percent health_exp total \\
\hline & 7 Percentage of Health Expenditure Over GSDP & percent_health_exp_gsdp \\
\hline & 8 Fiscal Health w.r.t. Own Revenue & fiscal_health_own \\
\hline & 9 Fiscal Health w.r.t. Total Revenue & fiscal health tot \\
\hline & 10 Per Capita Transfer & pc transfer \\
\hline & 11 Population Density & pop_density \\
\hline & 12 Percentage of Own Revenue w.r.t. Total Revenue & percent_own_tot_rev \\
\hline & 13 Percentage of Transfer w.r.t. Total Revenue & percent_trans_tot_rev \\
\hline & 14 Percentage of Calamity Relief w.r.t. Own Revenue & perctnt_calamity_relief_own_rev \\
\hline & 15 Percentage of Calamity Relief w.r.t. Total Revenue & percent_calamity_relief tot_rev \\
\hline & 16 Perc. of Calamity Relief w.r.t. Total Expenditure & percent_calamity_relief_tot_exp \\
\hline & 17 Percentage of Calamity Relief w.r.t. GSDP & percent_calamity_relief_gsdp \\
\hline & 18 Per Capita Calamity Relief & pc_calamity_relief \\
\hline & 19 Literacy Rate & literacy_rate \\
\hline & 20 Working Proportion of Population & working prop \\
\hline & 21 Human Development Index & Hdi \\
\hline & 22 Health Index & health_index \\
\hline & 23 Education Index & education index \\
\hline & 24 Income Index & income index \\
\hline & 25 Normalized Governance Index & n_governance \\
\hline & 26 Normalized Equity Indicator & n_equity \\
\hline
\end{tabular}

\footnotetext{
${ }^{9}$ Countrywide summary statistics of the variables are given in Table A1-A3 in the appendix
} 


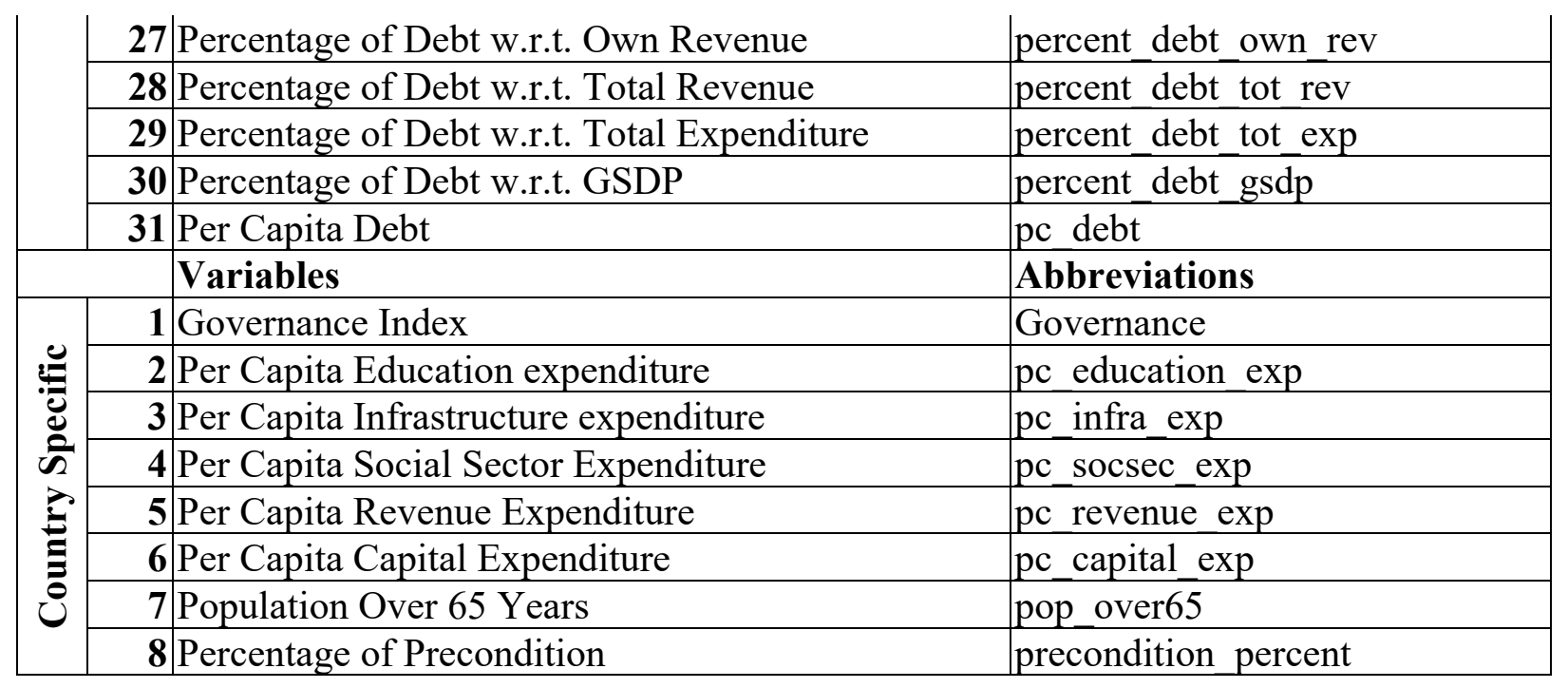

\section{Results \& Observations}

Stage 1

We find that the overall grand efficiency in COVID-19 pandemic management increased from $63 \%$ to $71 \%$ from $27^{\text {th }}$ August to $3^{\text {rd }}$ October, 2020. It reached $74 \%$ on $29^{\text {th }}$ November, 2020 (Table 4). This indicates that experience plays a role in managing the pandemic.

Table 4: Summary Statistics of Grand \& Group Efficiency for Three Periods

\begin{tabular}{|c|c|c|c|c|c|c|c|c|c|}
\hline \multicolumn{10}{|c|}{ AUG-27-2020 } \\
\hline & & Obs. & Mean & Median & SD & Skewness & Kurtosis & Min. & Max. \\
\hline \multirow{2}{*}{ IND } & Grand & 31 & 0.59 & 0.59 & 0.35 & -0.07 & 1.43 & 0.04 & 1.00 \\
\hline & Group & 31 & 0.74 & 1.00 & 0.33 & -0.71 & 1.87 & 0.08 & 1.00 \\
\hline \multirow{2}{*}{ MEX } & Grand & 32 & 0.63 & 0.56 & 0.28 & 0.20 & 1.41 & 0.28 & 1.00 \\
\hline & Group & 32 & 0.73 & 0.81 & 0.27 & -0.34 & 1.48 & 0.28 & 1.00 \\
\hline \multirow{2}{*}{ USA } & Grand & 50 & 0.65 & 0.67 & 0.29 & -0.20 & 1.76 & 0.13 & 1.00 \\
\hline & Group & 50 & 0.66 & 0.67 & 0.29 & -0.20 & 1.76 & 0.13 & 1.00 \\
\hline ALL & Grand & 113 & 0.63 & 0.64 & 0.30 & -0.10 & 1.62 & 0.04 & 1.00 \\
\hline \multicolumn{10}{|c|}{ OCT-03-2020 } \\
\hline & & Obs. & Mean & Median & SD & Skewness & Kurtosis & Min. & Max. \\
\hline \multirow{2}{*}{ IND } & Grand & 31 & 0.72 & 0.89 & 0.32 & -0.60 & 1.71 & 0.13 & 1.00 \\
\hline & Group & 31 & 0.79 & 1.00 & 0.30 & -0.91 & 2.18 & 0.16 & 1.00 \\
\hline \multirow{2}{*}{ MEX } & Grand & 32 & 0.70 & 0.64 & 0.24 & 0.00 & 1.60 & 0.30 & 1.00 \\
\hline & Group & 32 & 0.77 & 0.84 & 0.24 & -0.48 & 1.69 & 0.30 & 1.00 \\
\hline \multirow{2}{*}{ USA } & Grand & 50 & 0.72 & 0.82 & 0.29 & -0.58 & 1.91 & 0.15 & 1.00 \\
\hline & Group & 50 & 0.73 & 0.84 & 0.29 & -0.59 & 1.89 & 0.15 & 1.00 \\
\hline ALL & Grand & 113 & 0.71 & 0.78 & 0.29 & -0.49 & 1.84 & 0.13 & 1.00 \\
\hline
\end{tabular}




\begin{tabular}{|c|c|c|c|c|c|c|c|c|c|}
\hline \multicolumn{10}{|c|}{ NOV-29-2020 } \\
\hline & & Obs. & Mean & Median & SD & Skewness & Kurtosis & Min. & Max. \\
\hline \multirow{2}{*}{ IND } & Grand & 31 & 0.71 & 0.85 & 0.31 & -0.44 & 1.60 & 0.13 & 1.00 \\
\hline & Group & 31 & 0.82 & 1.00 & 0.27 & -1.15 & 2.78 & 0.21 & 1.00 \\
\hline \multirow{2}{*}{ MEX } & Grand & 32 & 0.76 & 0.73 & 0.20 & -0.36 & 2.37 & 0.29 & 1.00 \\
\hline & Group & 32 & 0.81 & 0.88 & 0.19 & -0.82 & 2.81 & 0.29 & 1.00 \\
\hline \multirow{2}{*}{ USA } & Grand & 50 & 0.75 & 0.83 & 0.27 & -0.88 & 2.52 & 0.14 & 1.00 \\
\hline & Group & 50 & 0.76 & 0.87 & 0.26 & -0.88 & 2.41 & 0.17 & 1.00 \\
\hline ALL & Grand & 113 & 0.74 & 0.81 & 0.26 & -0.71 & 2.31 & 0.13 & 1.00 \\
\hline
\end{tabular}

In the case of India, the average grand efficiency score was $59 \%$ on $27^{\text {th }}$ August, 2020

which was below the grand average. In the initial and final time periods taken for the study, India's average efficiency was lower than the grand average for the three countries. The results reflect that the USA was holding the leading position in terms of overall COVID-19 pandemic management at that time. For these two periods, the scores of Mexico were $70 \% \& 76 \%$ and the scores of the USA were $72 \%$ and $75 \%$. It is noted that the grand efficiency score of USA was always higher than the overall grand average for all the three periods.

If we compare the averages of Country Specific Group Efficiency scores the efficiency level of India and Mexico were almost same (74\% and 73\%) for $27^{\text {th }}$ August, 2020. However, in the case of the USA, the average group efficiency level is almost same with its grand efficiency level $(66 \%)$ on that time. This indicates that the states of the USA were performing consistently well with respect to their own country as well as other countries.

However, if we compare the grand and group efficiency scores of all three countries, we find that the states of India and Mexico were performing well in their own countries but doing worse than American states in terms of the global scenario on $27^{\text {th }}$ August. Again, it has been noted that, for all these three countries (India, Mexico, and the USA), the Country Specific Group Efficiency scores gradually increased on $3^{\text {rd }}$ October $(79 \%, 77 \%$, and $73 \%$, respectively) and $29^{\text {th }}$ November $(82 \%, 81 \%$, and $76 \%$, respectively). In terms of group efficiency score, we 
also find the states of India always perform better within the country than the states of other two countries. One plausible explanation of the better performance of India in terms of group efficiency could be the favorable recovery and fatality rates in the country.

\section{Stage 2}

\section{Median Analysis: Grand Efficiency Score}

Next, we use median analysis to recognize the association of efficiency scores generated in Stage 1 with the state finance and other demographic and socioeconomic variables. We identify the patterns of behavior of the variable concerned to explain the variations in efficiency with time. For example, when we find that the variable concerned has showed a pattern that, when moving from the LMG for HMG groups for the variable, the corresponding average efficiencies values have increased in all three time periods, we note that as 'increase-increaseincrease' pattern. Likewise, we can have patterns like 'decrease-decrease-decrease', 'increasedecrease-increase', and so forth. We tabulate monotone patterns like 'increase-increase-increase' and 'decrease-decrease-decrease' for the following discussions as they can be interpreted as smooth directions in movement of grand average efficiency scores with the variable of reference in Table 5.

For all three time periods, the state finance variables, such as per capita own revenue, per capita total revenue, per capita total expenditure, per capita health expenditure, and per capita transfer, are positively associated with average grand efficiency scores (reflected in an 'increaseincrease-increase pattern). Debt to total revenue or total expenditure ratio have a negative association (reflected through a decrease-decrease-decrease pattern) with average grand efficiency scores in all time periods. This clearly indicates that the state finances can play a role in managing the pandemic. Per capita GSDP and per capita calamity relief funds are also 
positively associated with average grand efficiency scores.

Among demographic variables, population density is negatively associated with average grand efficiency scores for August and November but shows a slight positive association in the early October data. The inconsistency can be explained by the two-way reasoning: firstly, higher population density is detrimental for preventing COVID-19 spread; thus, a negative association is not surprising. On the other hand, states with higher population density most likely contain more urban areas and are richer compared to low density states and thus may have the means to manage COVID better.

The percentage of working population has a positive role to play in all three time periods, but literacy rate does not have any consistent association with the average grand efficiency scores. The human development, health, and education indices are positively associated with average grand efficiency scores, but we do not find any consistent association of the income index with the same. Contrary to our expectation, the governance indicators have a negative association with average grand efficiency scores. This result may follow from the intuition that states with larger urban areas and higher population density may also have better governance indicators and, due to rapid spread of the virus, are less efficient in managing COVID.

Table 5: Median Analysis: Patterns in the Determinants of Grand Efficiency

\begin{tabular}{|l|l|}
\hline Monotone Patterns in Median Analysis & Variables \\
\hline \multirow{5}{*}{ increase-increase-increase } & Per Capita Own Revenue \\
\cline { 2 - 3 } & Per Capita Total Revenue \\
\cline { 2 - 2 } & Per Capita Total Expenditure \\
\cline { 2 - 2 } & Per Capita Health Expenditure \\
\cline { 2 - 2 } & Per Capita GSDP \\
\cline { 2 - 2 } & Per Capita Transfer \\
\cline { 2 - 2 } & Percentage of Own Revenue w.r.t. Total Revenue \\
\cline { 2 - 2 } & Percentage of Calamity Relief w.r.t. Own Revenue \\
\cline { 2 - 2 } & Perc. of Calamity Relief w.r.t. Total Expenditure \\
\cline { 2 - 2 } & Per Capita Calamity Relief \\
\cline { 2 - 2 } & Working Proportion of Population \\
\hline
\end{tabular}




\begin{tabular}{|l|l|}
\hline \multirow{5}{*}{ decrease-decrease-decrease } & Human Development Index \\
\cline { 2 - 2 } & Health Index \\
\cline { 2 - 2 } & Education Index \\
\hline & Perc. of Health Expenditure Over Total Expenditure \\
\cline { 2 - 2 } & Percentage of Health Expenditure Over GSDP \\
\hline & Fiscal Health w.r.t. Own Revenue \\
\cline { 2 - 2 } & Fiscal Health w.r.t. Total Revenue \\
\cline { 2 - 2 } & Percentage of Transfer w.r.t. Total Revenue \\
\cline { 2 - 2 } & Percentage of Debt w.r.t. Own Revenue \\
\cline { 2 - 2 } & Percentage of Debt w.r.t. Total Revenue \\
\hline & Percentage of Debt w.r.t. Total Expenditure \\
\hline & Percentage of Debt w.r.t. GSDP \\
\cline { 2 - 2 } & Normanize Governance Index \\
\cline { 2 - 2 } & Normalize Equity Indicator \\
\hline
\end{tabular}

\section{Median Analysis: Group Efficiency Score}

We also take the countries separately to see if there is any inherent difference in the association of indicators and group efficiency scores amongst different countries in different time periods (Table 6). For India, we find the relationships between group efficiency scores and state finance, socioeconomic, and demographic indicators to be similar to that of the grand efficiency scores in late August. In early October, the association of group efficiency scores with per capita own revenue and per capita GSDP reversed and became negative for unknown reasons, then reverted to its original positive association in late November. Population density is positively associated for all three time periods. Given the rural-urban divide in India, it is not surprising that states with bigger urban areas/more urban agglomeration are also the richer states able to handle the pandemic better. 
Table 6: Median Analysis: Patterns in the Determinants of Group Efficiency Scores

\begin{tabular}{|c|c|c|c|}
\hline $\begin{array}{l}\text { Monotone } \\
\text { Pattern }\end{array}$ & IND & USA & MEX \\
\hline \multirow{10}{*}{$\begin{array}{l}\text { increase- } \\
\text { increase- } \\
\text { increase }\end{array}$} & Per Capita Total Revenue & $\begin{array}{l}\text { Per Capita Total } \\
\text { Revenue }\end{array}$ & Per Capita Total Revenue \\
\hline & $\begin{array}{l}\text { Per Capita Total } \\
\text { Expenditure }\end{array}$ & & $\begin{array}{l}\text { Per Capita Total } \\
\text { Expenditure }\end{array}$ \\
\hline & & Per Capita GSDP & Per Capita GSDP \\
\hline & & $\begin{array}{l}\text { Percentage of Own } \\
\text { Revenue w.r.t. Total } \\
\text { Revenue }\end{array}$ & $\begin{array}{l}\text { Percentage of Own } \\
\text { Revenue w.r.t. Total } \\
\text { Revenue }\end{array}$ \\
\hline & Literacy Rate & & Literacy Rate \\
\hline & $\begin{array}{l}\text { Working Proportion of } \\
\text { Population }\end{array}$ & & $\begin{array}{l}\text { Working Proportion of } \\
\text { Population }\end{array}$ \\
\hline & $\begin{array}{l}\text { Human Development } \\
\text { Index }\end{array}$ & & $\begin{array}{l}\text { Human Development } \\
\text { Index }\end{array}$ \\
\hline & Health Index & & Health Index \\
\hline & Education Index & & Education Index \\
\hline & $\begin{array}{l}\text { Percentage of Calamity } \\
\text { Relief w.r.t. Total } \\
\text { Revenue }\end{array}$ & $\begin{array}{l}\text { Percentage of Calamity } \\
\text { Relief w.r.t. Total } \\
\text { Revenue }\end{array}$ & $\begin{array}{l}\text { Percentage of Calamity } \\
\text { Relief w.r.t. Total } \\
\text { Revenue }\end{array}$ \\
\hline \multirow[t]{7}{*}{$\begin{array}{l}\text { decrease- } \\
\text { decrease- } \\
\text { decrease }\end{array}$} & & $\begin{array}{l}\text { Percentage of Calamity } \\
\text { Relief w.r.t. Total } \\
\text { Expenditure }\end{array}$ & $\begin{array}{l}\text { Percentage of Calamity } \\
\text { Relief w.r.t. Total } \\
\text { Expenditure }\end{array}$ \\
\hline & $\begin{array}{l}\text { Percentage of Calamity } \\
\text { Relief w.r.t. GSDP }\end{array}$ & & $\begin{array}{l}\text { Percentage of Calamity } \\
\text { Relief w.r.t. GSDP }\end{array}$ \\
\hline & $\begin{array}{l}\text { Percentage of Debt w.r.t. } \\
\text { Own Revenue }\end{array}$ & $\begin{array}{l}\text { Percentage of Debt w.r.t. } \\
\text { Own Revenue }\end{array}$ & \\
\hline & $\begin{array}{l}\text { Percentage of Debt w.r.t. } \\
\text { Total Revenue }\end{array}$ & $\begin{array}{l}\text { Percentage of Debt w.r.t. } \\
\text { Total Revenue }\end{array}$ & \\
\hline & $\begin{array}{l}\text { Percentage of Debt w.r.t. } \\
\text { Total Expenditure }\end{array}$ & $\begin{array}{l}\text { Percentage of Debt w.r.t. } \\
\text { Total Expenditure }\end{array}$ & \\
\hline & $\begin{array}{l}\text { Percentage of Debt w.r.t. } \\
\text { GSDP }\end{array}$ & & $\begin{array}{l}\text { Percentage of Debt w.r.t. } \\
\text { GSDP }\end{array}$ \\
\hline & & Population Density & Population Density \\
\hline
\end{tabular}

For Mexico, in late August, per capita health expenditure did not have a role to play in explaining group efficiency scores. Per capita transfer and per capita calamity relief was negatively associated with group efficiency scores. Higher per capita transfer may be associated with worse fiscal health and may affect COVID management efficiency adversely. On the other hand, calamity relief funds are allocated to states that are more calamity-prone (in Mexico, those 
are more earthquake and storm prone), so higher per capita calamity relief fund may indicate worse socioeconomic conditions and infrastructure and thus worse COVID management capacity. The only change from late August to early October is that the per capita revenue reversed to a negative association with group efficiency scores, which reverted to a positive association again in late November data. Per capita transfer had an inconsistent relationship among the time periods. In late November, the governance indicator had a positive association with group efficiency scores. Unlike India, population density is negatively associated with group efficiency scores for all three time periods.

In USA, per capita health expenditure has a negative association with group in all time periods. There have been many inconsistencies in the nature of association of indicator and group efficiency scores among different time periods.

\section{Conclusions}

The paper attempts to establish the importance of subnational finances in COVID-19 management. Taking a sample of three of the worst affected countries, the USA, India, and Mexico, it first assesses the performances of the countries in managing the pandemic, both at the global and local levels. Second, it attempts to explore the roles of state finances, demographic factors, and socioeconomic factors in explaining state performances in COVID management. While the USA performs better than the other two countries as a whole, its efficiency scores are not that high. The exploratory analysis in the second stage indicates clearly that state finances have a role to play and can act as a catalyst in boosting the performances of all countries studied. This invites further study on the important policy implications of dividing the load of disaster response among central and subnational governments to achieve more successful COVID-19 management. 


\section{References}

Allain-Dupré, D., Chatry, I., Kornprobst, A., \& Michalun, M.-V. (2020). The territorial impact of COVID-19: Managing the crisis across levels of government. OECD.

Bandopadhyay, S., \& Roy Chowdhury, S. (2020). Management of COVID-19 in India: Can subnational finances tell a story? IMI Konnect, 9 (2), 3-18.

Banker, R.D., Charnes A., \& Cooper, W.W. (1984). Some models for estimating technical and scale inefficiencies in data envelopment analysis. Management Science, 30 (9), 1078-1092.

Battese, G.E., \& Rao, D.S.P. (2002). Technology gap, efficiency and a stochastic meta-frontier function. International Journal of Business and Economics, 1 (2), 87-93.

Battese, G.E., Rao, D.S.P., \& O’Donnell, C.J. (2004). A meta-frontier production function for estimation of technical efficiencies and technology gaps for firms operating under different technologies. Journal of Productivity Analysis, 21 (1), 91-103.

Buhler, R. H. (2018). The costs of the disaster the reconstruction funds. Voices of Mexico 105 (2018), 67-71.

Carter, W. N. (2008). Disaster management: A disaster manager's handbook. Asian Development Bank.

Charnes A., Cooper, W.W., \& Rhodes, E. (1978). Measuring the efficiency of decision making units. European Journal of Operation Research, 2 (6), 429-444.

Col, J.-M. Managing disasters: The role of local government. Public Administration Review, 67 (2007), 114-124.

Debreu, G. (1951). The coefficient of resource utilization. Econometrica, 19 (3), 273-292.

Dutta, A., \& Fischer, H.W. (2020). The local governance of COVID-19: Disease prevention and social security in rural India. World Development (2020), 105234.

Färe, R., Grosskopf, S., \& Lovell, C.A.K. (1985). The measurement of efficiency. Kluwer.

Farrell, M.J. (1957). The measurement of productive efficiency. Journal of Royal Statistical Society, Series A, 120 (3), 253-290.

Farrell, M.J., \& Fieldhouse, M. (1962). Estimating efficient production frontiers under IRS, Journal of the Royal Statistical Society, Series A, 125 (2), 252-267.

Hoffman, A.J. (1957). Discussion on Mr. Farrell's paper. Journal of the Royal Statistical Society, Series A, 120 (3), 284.

International Monetary Fund. Policy responses to COVID-19. https://www.imf.org/en/Topics/imf-and-COVID19/Policy-Responses-to-COVID-19\#I

Kapoor, G., et al. (2020). State-wise estimates of current hospital beds, intensive care unit (ICU) beds and ventilators in India: Are we prepared for a surge in COVID-19 hospitalizations? medRxiv. 
Koopmans, T.C. (1951). Analysis of production as an efficient combination of activities. In: Koopmans, T.C. (ed): Activity analysis of production and allocation. Wiley.

Maindiratta, A. (1990). Largest size efficient scale and size efficiencies of decision-making units in data envelopment analysis. Journal of Econometrics, 46 (1/2), 57-72.

Nemec, J., \& Špaček, D. (2020). The COVID-19 pandemic and local government finance: Czechia and Slovakia. Journal of Public Budgeting, Accounting \& Financial Management.

Raa, T.T. (2009). The Economics of Benchmarking: Measuring Performance for Competitive Advantage. Palgrave Macmillan.

Singh, D., Pandey, D. N., \& Mina, U. (2019). Earthquake - A natural disaster, prediction, mitigation, laws and government policies, impact on biogeochemistry of earth crust, role of remote sensing and GIS in management in India-an overview. Journal of Geosciences (Prague), 7 (2), 88-96. 


\section{Appendix}

Table A1: Summary Statistics of Second Stage Variables for India

\begin{tabular}{|c|c|c|c|c|c|c|}
\hline Sl. No. & Variables & Obs. & Mean & Std. Dev. & Min. & Max. \\
\hline 01 & pc_own_rev & 31 & 0.20 & 0.14 & 0.04 & 0.76 \\
\hline 02 & pc_tot_rev & 31 & 0.53 & 0.37 & 0.19 & 1.84 \\
\hline 03 & pc tot exp & 31 & 0.66 & 0.43 & 0.22 & 2.00 \\
\hline 04 & pc_health_exp & 31 & 0.03 & 0.03 & 0.01 & 0.13 \\
\hline 05 & pc_gsdp & 31 & 2.64 & 1.51 & 0.65 & 7.11 \\
\hline 06 & percent health exp total & 31 & 4.97 & 1.61 & 3.21 & 11.52 \\
\hline 07 & percent_health_exp_gsdp & 31 & 1.46 & 1.12 & 0.54 & 5.72 \\
\hline 08 & fiscal health_own & 31 & 428.96 & 351.97 & 128.32 & $1,323.87$ \\
\hline 09 & fiscal health tot & 31 & 126.59 & 10.39 & 108.74 & 143.24 \\
\hline 10 & pc_transfer & 31 & 0.33 & 0.36 & 0.05 & 1.65 \\
\hline 11 & pop_density & 31 & 884.53 & $2,243.62$ & 18.75 & $12,616.94$ \\
\hline 12 & percent own tot rev & 31 & 44.73 & 22.84 & 8.84 & 87.12 \\
\hline 13 & percent_trans_tot_rev & 31 & 55.27 & 22.84 & 12.88 & 91.16 \\
\hline 14 & perctnt_calamity relief_own rev & 31 & 3.14 & 2.54 & 0.18 & 13.73 \\
\hline 15 & percent calamity relief tot rev & 31 & 1.08 & 0.77 & 0.13 & 3.85 \\
\hline 16 & percent_calamity_relief_tot_exp & 31 & 0.88 & 0.67 & 0.09 & 3.44 \\
\hline 17 & percent_calamity_relief_gsdp & 31 & 0.22 & 0.20 & 0.02 & 1.13 \\
\hline 18 & pc_calamity_relief & 31 & 0.01 & 0.01 & 0.00 & 0.03 \\
\hline 19 & literacy_rate & 31 & 85.81 & 5.14 & 75.10 & 97.60 \\
\hline 20 & working prop & 31 & 0.41 & 0.05 & 0.33 & 0.52 \\
\hline 21 & hdi & 31 & 0.67 & 0.05 & 0.58 & 0.78 \\
\hline 22 & health index & 31 & 0.78 & 0.03 & 0.70 & 0.86 \\
\hline 23 & education_index & 31 & 0.59 & 0.06 & 0.48 & 0.73 \\
\hline 24 & income_index & 31 & 0.67 & 0.07 & 0.53 & 0.77 \\
\hline 25 & $\mathrm{n}$ governance & 31 & 0.00 & 0.60 & -1.21 & 1.10 \\
\hline 26 & n_equity & 31 & 0.00 & 0.98 & -2.29 & 1.89 \\
\hline 27 & percent_debt_own_rev & 31 & 68.48 & 57.46 & 0.00 & 295.04 \\
\hline 28 & percent_debt tot_rev & 31 & 23.05 & 14.35 & 0.00 & 74.36 \\
\hline 29 & percent_debt tot_exp & 31 & 17.74 & 10.13 & 0.00 & 54.22 \\
\hline 30 & percent_debt_gsdp & 31 & 4.67 & 3.06 & 0.00 & 15.76 \\
\hline 31 & pc_debt & 31 & 0.11 & 0.07 & 0.00 & 0.26 \\
\hline 32 & governance & 31 & 0.00 & 0.60 & -1.21 & 1.10 \\
\hline 33 & pc_education_exp & 31 & 0.09 & 0.06 & 0.04 & 0.25 \\
\hline 34 & pc infra_exp & 31 & 0.43 & 0.31 & 0.16 & 1.49 \\
\hline 35 & pc_socsec_exp & 31 & 0.26 & 0.16 & 0.10 & 0.69 \\
\hline 36 & pc_revenue_exp & 31 & 0.50 & 0.29 & 0.17 & 1.26 \\
\hline 37 & pc capital exp & 31 & 0.16 & 0.15 & 0.05 & 0.74 \\
\hline 38 & pop_over65 & 31 & 5.22 & 1.24 & 2.76 & 8.32 \\
\hline 39 & precondition_percent & NA & NA & NA & NA & NA \\
\hline
\end{tabular}


Table A2: Summary Statistics of Second Stage Variables for Mexico

\begin{tabular}{|c|c|c|c|c|c|c|}
\hline Sl. No. & Variables & Obs. & Mean & Std. Dev. & Min. & Max. \\
\hline 01 & pc own rev & 32 & 0.17 & 0.13 & 0.05 & 0.73 \\
\hline 02 & pc tot rev & 32 & 0.98 & 0.20 & 0.41 & 1.53 \\
\hline 03 & pc_tot_exp & 32 & 0.98 & 0.20 & 0.40 & 1.53 \\
\hline 04 & pc health_exp & 32 & 0.14 & 0.07 & 0.04 & 0.43 \\
\hline 05 & pc gsdp & 32 & 9.65 & 5.31 & 3.12 & 29.53 \\
\hline 06 & percent health_exp_total & 32 & 15.84 & 17.21 & 4.49 & 107.19 \\
\hline 07 & percent health_exp_gsdp & 32 & 1.49 & 0.35 & 0.53 & 2.14 \\
\hline 08 & fiscal_health_own & 32 & 787.31 & 373.11 & 208.64 & $1,646.59$ \\
\hline 09 & fiscal_health_tot & 32 & 99.90 & 0.55 & 96.88 & 100.00 \\
\hline 10 & pc transfer & 32 & 0.81 & 0.15 & 0.35 & 1.19 \\
\hline 11 & pop_density & 32 & 300.98 & $1,024.92$ & 11.77 & $5,851.76$ \\
\hline 12 & percent_own_tot_rev & 32 & 16.26 & 9.38 & 6.07 & 47.93 \\
\hline 13 & percent trans tot rev & 32 & 83.74 & 9.38 & 52.07 & 93.93 \\
\hline 14 & perctnt_calamity_relief_own_rev & 32 & 10.56 & 10.55 & 0.03 & 39.18 \\
\hline 15 & percent_calamity_relief_tot_rev & 32 & 1.35 & 1.22 & 0.01 & 4.44 \\
\hline 16 & percent calamity relief tot_exp & 32 & 1.35 & 1.22 & 0.01 & 4.44 \\
\hline 17 & percent_calamity_relief_gsdp & 32 & 0.20 & 0.26 & 0.00 & 1.05 \\
\hline 18 & pc_calamity_relief & 32 & 0.01 & 0.01 & 0.00 & 0.05 \\
\hline 19 & literacy rate & 32 & 93.74 & 3.66 & 84.20 & 97.70 \\
\hline 20 & working_prop & 32 & 0.44 & 0.03 & 0.37 & 0.50 \\
\hline 21 & hdi & 32 & 0.77 & 0.03 & 0.69 & 0.83 \\
\hline 22 & health index & 32 & 0.85 & 0.01 & 0.82 & 0.87 \\
\hline 23 & education_index & 32 & 0.69 & 0.05 & 0.58 & 0.83 \\
\hline 24 & income index & 32 & 0.77 & 0.04 & 0.68 & 0.81 \\
\hline 25 & $\mathrm{n}$ governance & 32 & 0.00 & 1.00 & -3.00 & 1.70 \\
\hline 26 & n_equity & 32 & 0.00 & 1.00 & -3.00 & 1.70 \\
\hline 27 & percent_debt_own_rev & 32 & 36.12 & 25.14 & 0.00 & 97.39 \\
\hline 28 & percent_debt_tot_rev & 32 & 6.61 & 6.92 & 0.00 & 31.61 \\
\hline 29 & percent_debt_tot_exp & 32 & 6.62 & 6.93 & 0.00 & 31.61 \\
\hline 30 & percent_debt_gsdp & 32 & 0.84 & 0.99 & 0.00 & 3.78 \\
\hline 31 & pc_debt & 32 & 0.07 & 0.09 & 0.00 & 0.48 \\
\hline 32 & governance & 32 & 0.39 & 0.03 & 0.29 & 0.45 \\
\hline 33 & pc_education_exp & NA & NA & NA & NA & NA \\
\hline 34 & pc infra_exp & NA & NA & $\mathrm{NA}$ & NA & NA \\
\hline 35 & pc_socsec_exp & $\mathrm{NA}$ & $\mathrm{NA}$ & $\mathrm{NA}$ & $\mathrm{NA}$ & $\mathrm{NA}$ \\
\hline 36 & pc_revenue_exp & NA & NA & NA & NA & NA \\
\hline 37 & pc_capital_exp & $\mathrm{NA}$ & NA & NA & NA & NA \\
\hline 38 & pop_over65 & 32 & 44.07 & 2.81 & 37.30 & 49.91 \\
\hline 39 & precondition percent & NA & NA & NA & NA & NA \\
\hline
\end{tabular}




\section{Table A3: Summary Statistics of Second Stage Variables for USA}

\begin{tabular}{|c|c|c|c|c|c|c|}
\hline SI. No. & Variables & Obs. & Mean & Std. Dev. & Min. & Max. \\
\hline 01 & pc_own_rev & 50 & 6.11 & 1.54 & 3.49 & 9.32 \\
\hline 02 & pc tot rev & 50 & 8.35 & 1.99 & 5.08 & 13.63 \\
\hline 03 & pc tot_exp & 50 & 7.67 & 2.11 & 4.46 & 16.46 \\
\hline 04 & pc health exp & 50 & 0.19 & 0.12 & 0.05 & 0.59 \\
\hline 05 & pc_gsdp & 50 & 58.65 & 11.21 & 38.65 & 86.13 \\
\hline 06 & percent health exp total & 50 & 2.36 & 1.26 & 0.65 & 5.59 \\
\hline 07 & percent_health_exp_gsdp & 50 & 0.31 & 0.19 & 0.11 & 1.10 \\
\hline 08 & fiscal_health_own & 50 & 126.35 & 16.77 & 93.66 & 185.38 \\
\hline 09 & fiscal health tot & 50 & 91.68 & 7.29 & 77.35 & 120.77 \\
\hline 10 & pc_transfer & 50 & 2.23 & 0.70 & 1.28 & 4.75 \\
\hline 11 & pop_density & 50 & 66.13 & 80.32 & 0.42 & 393.00 \\
\hline 12 & percent_own tot rev & 50 & 73.13 & 5.20 & 63.40 & 82.59 \\
\hline 13 & percent_trans_tot_rev & 50 & 26.87 & 5.20 & 17.41 & 36.60 \\
\hline 14 & perctnt calamity relief own rev & 50 & 4.72 & 6.58 & 0.00 & 35.41 \\
\hline 15 & percent_calamity relief tot rev & 50 & 3.37 & 4.40 & 0.00 & 23.07 \\
\hline 16 & percent_calamity_relief_tot_exp & 50 & 3.65 & 4.60 & 0.00 & 27.02 \\
\hline 17 & percent_calamity relief gsdp & 50 & 0.53 & 0.83 & 0.00 & 4.26 \\
\hline 18 & pc calamity relief & 50 & 0.33 & 0.59 & 0.00 & 3.14 \\
\hline 19 & literacy_rate & 50 & 88.36 & 4.31 & 77.00 & 94.00 \\
\hline 20 & working prop & 50 & 0.62 & 0.05 & 0.52 & 0.71 \\
\hline 21 & hdi & 50 & 0.92 & 0.02 & 0.86 & 0.96 \\
\hline 22 & health_index & 50 & 0.90 & 0.03 & 0.85 & 0.94 \\
\hline 23 & education index & 50 & 0.91 & 0.02 & 0.86 & 0.94 \\
\hline 24 & income index & 50 & 0.95 & 0.03 & 0.89 & 1.00 \\
\hline 25 & $\mathrm{n}$ _governance & 50 & 0.00 & 1.00 & -2.75 & 1.25 \\
\hline 26 & n_equity & 50 & 0.00 & 1.00 & -2.75 & 1.25 \\
\hline 27 & percent_debt_own_rev & 50 & 60.45 & 30.68 & 16.19 & 152.84 \\
\hline 28 & percent_debt_tot_rev & 50 & 44.17 & 22.90 & 11.09 & 114.71 \\
\hline 29 & percent_debt tot_exp & 50 & 47.99 & 24.91 & 13.49 & 143.52 \\
\hline 30 & percent_debt_gsdp & 50 & 6.30 & 3.21 & 1.66 & 15.01 \\
\hline 31 & pc_debt & 50 & 3.81 & 2.44 & 0.91 & 11.39 \\
\hline 32 & governance & 50 & 0.74 & 0.11 & 0.44 & 0.88 \\
\hline 33 & pc_education_exp & 50 & 2.25 & 0.57 & 1.32 & 4.62 \\
\hline 34 & pc infra exp & 50 & 1.08 & 0.48 & 0.44 & 3.35 \\
\hline 35 & pc_socsec_exp & 50 & 6.66 & 1.83 & 4.00 & 14.35 \\
\hline 36 & pc_revenue_exp & NA & NA & NA & NA & NA \\
\hline 37 & pc_capital_exp & NA & NA & $\mathrm{NA}$ & NA & NA \\
\hline 38 & pop_over65 & 50 & 16.37 & 1.91 & 10.74 & 20.45 \\
\hline 39 & precondition_percent & 50 & 0.51 & 0.01 & 0.46 & 0.53 \\
\hline
\end{tabular}

